\title{
Editorial
}

\section{Another Brexit Hard Reality - in Thanks to Advocate General Sharpston}

\author{
Lorenzo Squintani \\ University of Groningen, Groningen, The Netherlands \\ l.squintani@rug.nl
}

On August, $30^{\text {th }} 2019$, the participants to the $7^{\text {th }}$ EELF Conference, among whom myself, listened with great regard, interest and attention to the keynote titled 'Facilitating access to courts to improve the enforcement of sustainability' provided by the (then) Advocate General Eleonor Sharpston. ${ }^{1}$ Her consideration that "However well-drafted legislative provisions to improve sustainability may be, their impact will be limited unless there are also appropriate enforcement mechanisms", finds confirmation in the many cases delivered at EU and national level, including those presented in the Case Law Report to this issue. $^{3}$

By the time this editorial will be published, Advocate General Sharpston will have left the Court of Justice of the European Union where she served for

1 Eleanor Sharpston, Facilitating access to courts to improve the enforcement of sustainability, Utrecht 30 August 2019, a synopsis of which is available on the website of the organising insitution, the Utrecht University, at: https://www.uu.nl/en/utrecht-centre-for-water-oceansand-sustainability-law/eelf-2019-conference.

2 Ibidem.

3 See in particular Case C-535/18 Land Nordrhein-Westfalen ECLI:EU:C:2020:391, reported in L. Squintani, Case Law of the Court of Justice of the European Union and the General Court Reported Period 01.01.2019-01.09.2020, JEEPL 2020 17(4). 
almost three lustra. This is just one of the concrete consequences of Brexit, ${ }^{4}$ a sad one I would like to add. ${ }^{5}$

Indeed, a quick look at the contributions published in this journal in the last decade shows the great influence that Sharpston has had on the development of environmental protection in the European Union, including the EU Member States legal orders. ${ }^{6}$ Her most influential work focuses on judicial protection, as well known to the readers of this journal. ${ }^{7}$ Her opinions and literary work are not only characterized by great legal competence, but also by the ability to master rhetoric. Sharpston's Opinion in the Bund case, with the 'Ferrari with its doors locked shut' metaphor, being emblematic in both regards. ${ }^{8}$ This journal therefore would like to thank Eleonore Sharpston for her contribution to the protection of the environment in the European Union in her vest of Advocate General to the CJEU and look forward to appreciate her further contributions to the field.

To this extent, this issue contains two manuscripts looking exactly at judicial protection and enforcement in environmental matters. First, Jerzy Jendrośka's

4 The matter is not settled though as a case aiming at Sharpston's reinstatement is pending, see in particular, Sharpston v Council and Conférence des Représentants des Gouvernements des États membresCase T-180/20.

5 For a more detailed discussion on and reactions to this development, see https://verfassungs blog.de/its-urgent/; https://verfassungsblog.de/its-urgent-ii/ ; and https://verfassungsblog .de/its-urgent-iii/; https://verfassungsblog.de/could-there-be-a-rule-of-law-problem-at-the -eu-court-of-justice/; https://verfassungsblog.de/the-schroedingers-advocate-general/.

6 See in this regard, e.g. J. Kokott and C. Sobotta The Contribution of the Case Law of the CJEU to the Judicial Enforcement of EU Environmental Law in the UK Authors, JEEPL 2019 16(2).

7 E.g. H. Schoukens , Granting Legal Personhood to Nature in the European Union: Contemplating a Legal (R)evolution to Avoid an Ecological Collapse? (Part ii), JEEPL 2019 16(1); H. Schoukens, The Quest for the Holy Grail and the Dutch Integrated Approach to Nitrogen: How to Align Adaptive Management Strategies with the EU Nature Directives?, JEEPL 2018 15(2); B. W. Wegener, European Right of Action for Environmental NGOs, JEEPL 2011 8(4); D. McGillivray Mitigation, Compensation and Conservation: Screening for Appropriate Assessment under the EU Habitats Directive, JEEPL 2011 8(4); J. Darpö, Article 9.2 of the Aarhus Convention and EU Law Author, JEEPL 2014 11(4); J Darpö, On the Bright Side (of the EU's Janus Face) The EU Commission's Notice on Access to Justice in Environmental Matters, JEEPL 2017 14(3-4); T. Schomerus, Access to Information on Legislative Proceedings - Case Note on Judgment of the Court (2nd Chamber) of 18 July 2013 - C 515/11, JEEPL 2013 10(4); and L. Krämer, Comment on case C-240/og Lesoochranárske zoskupenie VLK: Access to justice in environmental matters: new perspectives, JEEPL 2011 8(4).

8 Opinion of Advocate General Sharpston, Case C-115/og, Bund für Umwelt und Naturschutz Deutschland, Landesverband Nordrhein-Westfalen eV, Bund für Umwelt und Naturschutz Deutschland, Landesverband Nordrhein-Westfalen eV. ECLI:EU:C:2010:773. For an analysis of what occurred after this opinion, see M. Eliantonio and F. Grashof, Wir müssen reden! - We Need to Have a Serious Talk, JEEPL 2016 13(3-4). 
manuscript, complementing his earlier work in this journal, ${ }^{9}$ helps us to look at the future of access to justice in environmental matters, by explaining the origins of the legal framework that influences both EU and national law the most in this regard, the Aarhus Convention. Second, Delphine Misonne's manuscript reminds us of the importance of the enforcement of EU environmental law, and limitations existing under EU law in this regard. Specifically, she analyses the peculiar situation occurring in Germany in which, following on the unwillingness to comply with the Janecek judgment, ${ }^{10}$ parties asked for the criminal prosecution of public officials. ${ }^{11}$ Air quality is also the central topic of discussion of the last contribution to this issue. Katarzyna Swiech-Kujawska's manuscript looks indeed at the manner in which economic instruments can improve air quality, by focusing on Poland as a case study.

I wish the readers a pleasant reading!

9 J. Jendrośka, Aarhus Convention and Community Law: the Interplay, JEEPL 2005 2(1); J. Jendrośka, Public participation in the preparation of plans and programs: some reflections on the scope of obligations under Article 7 of the Aarhus Convention, JEEPL 2009 6(4); J. Jendrośka, Aarhus Convention Compliance Committee: Origins, Status and Activities, JEEPL 2011 8(4); J. Jendrośka, Citizen's Rights in European Environmental Law: Stock-Taking of Key Challenges and Current Developments in Relation to Public Access to Information, Participation and Access to Justice, JEEPL 2012 9(1).

10 Case C-237/o7 Janecek [2008] ECLI:EU:C:2008:447.

11 Case C-752/18 Deutsche Umwelthilfe eVvFreistaat Bayern [2019] ECLI:EU:C:2019:1114. 